\title{
ZIMBABWE
}

\section{JOURNAL OF AGRICULTURAL RESEARCH}

Vol. 19, No. 1

1981

\section{CONTENTS}

\section{Animal Production}

Cell counts of bulked milks of dairy herds over four years, by Marion Titterton and J. Oliver

\section{Pastures}

The responses of four grasses to applied nitrogen on two soils, by M.G.W. Rodel, J.N. Boultwood and Lindsay McNeill

\section{Soil Fertility}

Residual effects of grass leys on the productivity of sandy granite-derived soils, by D. L. Barnes

1. Harvested leys

2. Grazed leys

\section{Soil Chemistry}

Methods of measuring available zinc in Zimbabwean soils, by T. J.T. Madziva

\section{Tobacco}

Effects of nitrogen, phosphorus and potassium on flue-cured tobacco in Zimbabwe, by W. W. Ryding

\section{Groundnuts}

Diseases of groundnut (Arachis hypogaea L.), by Desiree L. Cole

1. Fungicide spray effects on Cercospora arachidicola and Phoma arachidicola leaf infection, kernel yield and pod rots

\section{Entomology}

The female sex pheromone of the maize stalk-borer Busseola fusca (Fuller) (Lepidoptera: Noctuidae): identification and initial field trials, by D. R. Hall, P.S. Beevor, A. Cork, R. Lester, Brenda F. Nesbitt, G. K.C. Nyirenda, D.D. Nota Phiri, B.W. Blair and J. Tannock

\section{Notice to Subscribers}

Subscribers are advised that with effect from Vol. 20, No. 1 (1982) the annual subscription is to be increased from Z. $\$ 6,00$ to Z. $\$ 10,00$ for subscribers in Zimbabwe and adjoining territories, and from U.S. $\$ 10,00$ to U.S. $\$ 16,00$ for subscribers elsewhere. Thus, when renewing your subscription for 1982, please ensure that the revised rate is submitted.

The Department of Research and Specialist Services heavily subsidizes the publication of this Journal, and the increase in subscription has been kept to a minimum to encourage your continued support.

\section{Enquiries to}

The Editor,

Zimbabwe Journal of Agricultural Research,

P.O. Box 8108, Causeway, Salisbury, Zimbabwe. 


\title{
TROPICAL AGRICULTURE ASSOCIATION
}

The Tropical Agriculture Association is a new society of professionals and trainees in the broad field of Tropical, Sub-Tropical and Arid Zone Agriculture and Rural Development. Members share a common interest in the exchange and wider dissemination of practical information on rural development, based on agriculture in its widest sense.

During 1980-81 the Association has held three technical meetings, namely:

Appropriate Technology (December 1980),

Tropical Root Crops (10 April 1981), and

Training in Tropical Agriculture (16 June 1981).

and further meetings are being planned. A newsletter containing information, articles and letters is published thrice annually.

The Association will welcome new members; the Annual Subscription for those who are qualified and practising is $f 3$ in 1981 and $f 1.50$ for those. who are still qualifying. The Association is also seeking corporate sponsors, i.e. commercial organisations working in this field.

Further information may be obtained from the Hon. Secretary,

TROPICAL AGRICULTURE ASSOCIATION

Land Resources Development Centre, Tolworth Tower, Surbiton, Surrey KT6 7DY

\section{THE JOURNAL OF ACRICULTURAL SCIENCE}

\author{
Editors \\ SIR JAMES W. L. BEAMENT \\ Drapers Professor of Agriculture, University of Cambridge \\ W. J. RIDGMAN \\ Department of Applied Biology, University of Cambridge
}

The Journal of Agricultural Science publishes research in both pure and applied sciences relating to agricultural problems. A wide range of topics is considered in soil science, crop research and research on farm animals, including crop and animal husbandry, nutrition, physiology, genetics and breeding. Papers on broader ecological and environmental subjects are included if they are relevant to agricultural practice. The journal receives contributions from all parts of the world, thus providing information on agriculture in a wide variety of soil and climatic conditions.

\author{
Volume 96: February, April and June 1981 \\ Volume 97: August, October and December 1981

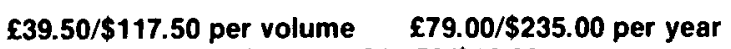 \\ Single parts: $£ 15.50 / \$ 46.00$

\section{CAMBRIDGE UNIVERSITY PRESS}

The Edinburgh Building, Shaftesbury Road, Cambridge CB2 2RU, England 32 East 57 th Street, New York, N.Y. 10022, U.S.A. 


\section{New from Butterworths - an important title on a subject of great current interest}

\section{Biological Husbandry A Scientific Approach to Organic Farming}

Bernard Stonehouse

\section{2 pages $£ 25.00$}

Acknowledged experts in biological husbandry write on a wide range of topics: the interrelationships of soil, flora and fauna; agricultural methods, including biological pest control, problems of energy saving and recycling and an assessment of the limits to productivity; the application of methods of organic farming to a variety of agricultural systems; studies of energy utilization, crop quality and yield; and the economics of biological husbandry as compared with conventional agriculture. There is a section devoted specifically to biological husbandry in the tropics.

In presenting both review papers on the technical, practical and economic aspects of the subject and reports on recent experimental research in temperate and tropical regions, the book will be an important reference work and act as a stimulus to further research in biological husbandry. As such, it will be of interest to agriculturalists, whether research workers, advisory staffs or farmers, as well as those in closely related disciplines such as applied biology, ecology, and environmental science.

Order today from your Bookseller. Further details available from Butterworths, Borough Green, Sevenoaks, Kent, TN15 8PH 


\title{
EXPERIMENTAL
}

AGRICULTURE

VOLUME 171981

\author{
Editor \\ PROFESSOR J. P. HUDSON \\ Book Review Editor \\ PROFESSOR N. W. SIMMONDS \\ Editorial Board
}

PROFESSOR E. W. RUSSELL (Chairman)

\begin{abstract}
PROFESSOR A. H. BUNTING
A. R. MELVILLE

DR I. CARRUTHERS

PROFESSOR J. L. MONTEITH

DR R. K. CUNNINGHAM

DR R. D. STERN

PROFESSOR J. D. IVINS

DR G. WATTS PADWICK
\end{abstract}

DR C. C. WEBSTER

\author{
CAMBRIDGE UNIVERSITY PRESS \\ CAMBRIDGE \\ LONDON NEW YORK NEW ROCHELLE \\ MELBOURNE SYDNEY
}


PUBLISHED BY

THE PRESS SYNDICATE OF THE UNIVERSITY OF CAMBRIDGE

The Pitt Building, Trumpington Street, Cambridge CB2 1RP

32 East 57 th Street, New York, N.Y. 10022

(c) Cambridge University Press 1981 


\section{CONTENTS}

\section{Part 1 (January 1981)}

R. C. Hills and J. H. T. Morgan: Rainfall Statistics: An Interactive Approach to Analysing Rainfall Records for Agricultural Purposes (Methodology of Experimental Agriculture - Number 9)

J. A. Warren and I. Mendez: Block Size and Orientation and Allowance for Positional Effects, in Field Experiments (Methodology of Experimental Agriculture - Number 10)

C. S. Kamara: Effects of Planting Date and Mulching on Cowpea in Sierra Leone

M. J. S. Magambo and M. G. R. Cannell: Dry Matter Production and Partition in Relation to Yield of Tea

J. B. Butler and N. W. Pirie: An Improved Small Scale Unit for Extracing Leaf Juice

P. N. Takkar and V. K. Nayyar: Effects of Gypsum and Zinc on Rice Nutrition on Sodic Soil

I. P. S. Ahlawat, A. Singh and C. S. Saraf: Effects of Winter Legumes on the Nitrogen Economy and Productivity of Succeeding Cereals

R. W. Willey and M. R. Rao: A Systematic Design to Examine Effects of Plant Population and Spatial Arrangement in Intercropping, Illustrated by an Experiment on Chickpea/Safflower

T. M. Yegappan and B. J. Mainstone: Comparisons between Press and Pressure Chamber Techniques for Measuring Leaf Water Potential

A. S. Abubaker and A. M. Gurnah: Effects of Weeding and Row Spacing on Sugarcane at theKenya Coast

M. T. Dahniya, C. O. Oputa and S. K. Hahn: Effects of Harvesting Frequency on Leaf and Root Yields of Cassava

O. Babalola and C. Oputa: Effects of Planting Patterns and Population on Water Relations of Maize

S. S. Prihar, K. S. Sandhu, K. L. Khera and B. S. Sandhu: Effects of Irrigation Schedules on Yield of Mustard (Brassica juncea)

Book Reviews

\section{Part 2 (April 1981)}

J. L. Monteith, P. J. Gregory, B. Marshall, C. K. Ong, R. A. Saffell and G. R. Squire: Physical Measurements in Crop Physiology I. Growth and Gas Exchange (Methodology of Experimental Agriculture - Number 11) 
J. H. C. Davis, M. C. Amézquita and J. E. Muñoz: Border Effects and Optimum Plot Sizes for Climbing Beans (Phaseolus vulgaris) and Maize in Association and Monoculture (Methodology of Experimental Agriculture - Number 12)

D. I. T. Walker and N. W. Simmonds: Comparisons of the Performance of Sugarcane Varieties in Trials and in Agriculture

E. G. Hallsworth: The Use of Saline Groundwater in Arid Areas

T. W. Tanton: The Banjhi (Dormancy) Cycle in Tea (Camellia sinensis)

R. D. Misra and P. C. Pant: Criteria for Scheduling the Irrigation of Wheat

W. Y. Chew, K. T. Joseph and K. Ramli: Influence of Liming and Soil $\mathrm{pH}$ on Sorghum (S. bicolor) and Groundnut (Arachis hypogaea) in Acid Tropical Malaysian Peat

W. Y. Chew, K. T. Joseph, K. Ramli and A. B. A. Majid: Influence of Liming and Soil $\mathrm{pH}$ on Cassava (Manihot esculenta) in Tropical Oligotrophic Peat

Y. Kapulnik, S. Sarig, I. Nur, Y. Okon, J. Kigel and Y. Henis: Yield Increases in Summer Cereal Crops in Israeli Fields Inoculated with Azospirillum

M. A. Taha, M. N. A. Malik, F. I. Chaudhry and M. I. Makhdum: Heatinduced Sterility in Cotton Sown during Early April in West Punjab

M. A. B. Fakorede and D. K. Ojo: Variability for Seedling Vigour in Maize

R. C. Hawkins and P. J. M. Cooper: Growth, Development and Grain Yield of Maize

Peter Felker, G. H. Cannell and Peter R. Clark: Variation in Growth Among 13 Prosopis (mesquite) Species

Book Reviews

\section{Part 3 (July 1981)}

G. R. Squire, C. R. Black and P. J. Gregory: Physical Measurements in Crop Physiology. II. Water Relations (Methodology of Experimental Agriculture - Number 13)

K. Ryder: Field Plans: Why the Biometrician Finds them Useful (Methodology of Experimental Agriculture - Number 14)

R. W. Willey and M. S. Reddy: A Field Technique for Separating Aboveand Below-Ground Interactions in Intercropping: an Experiment with Pearl Millet/Groundnut (Methodology of Experimental Agriculture Number 15)

K. R. Howse: A Technique for Using Permanent Neutron Meter Access Tubes in Cultivated Soils (Methodology of Experimental Agriculture Number 16) 
P. W. Bartholomew and R. J. Williams: Nitrogen Application for ShortTerm Forages in Saudi Arabia. I. Winter Annuals: Wheat, Oats and Italian Ryegrass

P. W. Bartholomew and R. J. Williams: Nitrogen Application for ShortTerm Forages in Saudi Arabia. II. Summer Annuals: Maize, Proso Millet and Foxtail Millet

N. Thomas and J. M. Farias: Intensive Forage Production in Northern Mexico. I. Responses of Italian Ryegrass to Nitrogen and Irrigation

U. P. de S. Waidyanatha and D. K. Angammana: Early Exploitation of Hevea Rubber Trees by Puncture and Short-Cut Tappings

R. L. Yadav: Intercropping Pigeonpea to Conserve Fertilizer Nitrogen in Maize and Produce Residual Effects on Sugarcane

Jill E. Wilson: Effects of Formulation and Method of Applying Gibberellic Acid on Flower Promotion in Cocoyam

T. W. Tanton: Growth and Yield of the Tea Bush

Jagdish Seth and K. I. Mosluh: Effects of Urea Spray on Wheat in Iraq

F. F. Bebawi and A. F. Farah: Effects of Patterns and Methods of Sowing on Sorghum/Striga Relations

Book Reviews

\section{Part 4 (October 1981)}

D. J. Finney: The Misuse of Methematicians, Statisticians and Computers in Agricultural Research (Methodology of Experimental Agriculture - Number 17)

N. W. Simmonds: Genotype $(G)$, Environment $(E)$ and $G E$ Components of Crop Yields (Methodology of Experimental Agriculture - Number 18)

R. J. Summerfield and F. J. Muehlbauer: Controlled Environments as an Adjunct to Field Research on Lentils (Lens culinaris). I. Perspectives, Tenets and Objectives (Methodology of Experimental Agriculture Number 19)

C. D. S. Bartlett and J. M. Fajemisin: The Social-Scientist's Role in Generating Innovations for Small Farmers: Maize in Nigeria (Methodology of Experimental Agriculture - Number 20)

A. R. Bromfield, I. R. Hancock and D. F. Debenham: Effects of Ground Rock Phosphate and Elemental S on Yield and P Uptake of Maize in Western Kenya

A. H. Choudhary: Effects of Population and Inter-Row Spacing on Yields of Maize and Control of Weeds with Herbicides in the Irrigated Savanna 
S. O. Ojeniyi, N. E. Egbe and T. I. Omotosho: Boron Nutrition of Amazon Cocoa (Cacao theobroma) in Nigeria. I. Early Results of Fertilizer Trials

F. A. Gumbs and L. A. Simpson: Influence of Flooding and Soil Moisture Content on Elongation of Sugarcane in Trinidad

T. A. T. Wahua, O. Babalola and M. E. Aken'ova: Intercropping Morphologically Different Types of Maize with Cowpeas: LER and Growth Attributes of Associated Cowpeas

F. F. Bebawi and A. F. Farah: Effects of Parasitic and Non-Parasitic Weeds on Sorghum

F. F. Bebawi: Intraspecific Physiological Variants of Striga hermonthica

F. F. Bebawi and A. F. Farah: Effects of Nitrophoska and Atrazine on relations between Sorghum bicolor and Striga hermonthica

Book Reviews

Erratum

Index 
should not be more than 80 typewriter characters wide, including spaces between words, figures and columns.

Typescripts. The top copy and one carbon copy of the script should be submitted, typed with double spacing, on one side of the paper only and with margins of about $1 \frac{1}{2}$ inches at the left-hand side and head of each sheet. Quarto or $\mathrm{A}_{4}$ sizes are preferred to foolscap.

Title. The development of automatic bibliographic methods, based on indexing the significant words in the title, make it essential that the title of each paper should contain the maximum of useful information. It is particularly important, for example, that the title should contain references, where relevant, to the crop, the character of the investigation, the factors under review, and the climatic or geographic area in which the work was done.

Headings. The following details should be given at the head of the first sheet: the full title of the paper; a short title for running headlines, not exceeding 48 characters, sounting each letter and space as one character; the name(s) of the author(s); the address at which the work was carried out; the present address(es) of author(s), if different from the previous item; and the address(es) to which proofs should be sent (see under 'Proofs' below).

Summary. A short but accurate and informative summary must be included, not larger than ten lines of typescript. The preparation of the summary, which requires much care, is not an Editorial responsibility.

Experimentation. This journal specialises in the presentation of data based on up-to-date methods of field experimentation. It is therefore important, where appropriate, that papers should include: an adequate account of experimental lay-outs; a description of treatments and general management; and assessments of experimental variability (c.g. coefficient of variation) and of the statistical significance of the results, specifying the methods used for the analysis (but without showing any details of the calculations). Papers can rarely be accepted if the work was carried out in containers, and/or under glasshouse conditions, unless it forms part of an investigation on field problems. Most agronomic investigations require at least two years of experimentation because of the variable effects of weather; papers based on a single season's work are not usually acceptable. The journal does not normally publish accounts of straightforward trials of pesticides, herbicides or varieties, since such papers are usually of local interest only.

Plates. Illustrations are welcome if they contribute to an understanding of the paper, but will only be accepted if of high quality. Photographs should be provided as unmounted glossy black-and-white prints (colour prints, but not colour transparencies, are acceptable for reproduction in black-and-white; they can only be reproduced in colour if a financial subsidy is provided). If lettering is to be inserted on a print, this should be shown on a spare copy or an overlay, and an unmarked print should be provided for marking by the printer.

Figures. Diagrams, including lettering should be in Indian ink on white drawing paper. Each illustration should bear the name of the author(s) and the figure number, written clearly in the margin or on the back. On no account should diagrams be submitted on sheets larger than foolscap size, and preferably not larger than $\mathrm{A}_{4}$.

Legends. The legends for all illustrations should be given on separate sheets of paper, clearly marked with the number of each plate or diagram. The ideal position for each diagram should be marked in the text, although it may not be possible to put the illustration exactly in that place.

Dating the work. Dates should be given for the beginning event of each experiment. The journal is reluctant to accept papers submitted more than three years after the end of the relevant experimental work.

Tables. Each table should be typed on a separate sheet of paper, and its preferred position indicated on the typescript. Each table should be numbered and bear an appropriate legend, along the lines normally used for tables in this publication. Contributors are specially asked to avoid presenting tables that are too large to print across the page, hence the limit of 80 typewriter characters referred to earlier. (N.B. It is rarely necessary to cite results to more than three significant figures in tables.)

Use of metric units. All data must be presented in metric units. Comparable data in local units (e.g. acres, ounces, etc.) may be given in parentheses at the first mention, or factors for converting metric into local units may be given as footnotes. The use of SI units will probably become mandatory at some time in the future.

References. The Harvard system of citation is used throughout. In the list of references all authors' names should be given. Not more that fifteen papers should normally be cited. It is preferable not to cite publications that are not readily accessible, such as theses.

Referees. All manuscripts are critically reviewed by expert referees, on whose advice the Editor accepts or rejects contributions, or returns them to authors for reconsideration.

Proofs. Two sets of single-sided page proofs will be sent to each author, but it is the responsibility of the senior author to collate the views of his co-author(s) and submit a consolidated set of corrections to the Editor, by returning to him the printer's marked proof (identified by the words 'marked copy') with all required corrections. No further corrected proof will be sent to the author(s), unless this is specially requested. Excessive alterations, other than corrections of printer's errors, may be disallowed or charged to the author.

Offprints. Fifty offprints will be sent free of charge to the author(s). Where there are two or more authors, all fifty offprints will be sent to the senior author, unless the printer is asked to divide them. Additional offprints may be ordered on the form sent out with the proofs (to the senior author only if there is more than one) provided this is returned to the printer within seven days of its receipt by the author.

Return of manuscript. Where a submission is not accepted for publication the top copy will be returned; manuscripts on thin (air-mail) paper will usually be sent by air but bulky manuscripts from overseas may be returned by surface mail. 


\section{EXPERIMENTAL AGRICULTURE VOLUME 17, NUMBER 4, OCTOBER 198I}

\section{CONTENTS}

D. J. Finney: The Misuse of Mathematicians, Statisticians and Computers in Agricultural Research (Methodology of Experimental Agriculture-Number 17)

N. W. Simmonds: Genotype $(G)$, Environment $(E)$ and $G E$ Components of Crop Yields (Methodology of Experimental AgricultureNumber 18 )

R. J. Summerfield and F. J. Muehlbauer: Controlled Environments as an Adjunct to Field Research on Lentils (Lens culinaris) I. Perspectives, Tenets and Objectives (Methodology of Experimental Agriculture-Number 19)

C. D. S. Bartlett and J. M. Fajemisin: The Social-Scientist's Role in Generating Innovations for Small Farmers: Maize in Nigeria (Methodology of Experimental Agriculture-Number 20)

A. R. Bromfield, I. R. Hancock and D. F. Debenham: Effects of Ground Rock Phosphate and Elemental S on Yield and P Uptake of Maize in Western Kenya

A. H. Choudhary: Effects of Population and Inter-row Spacing on Yields of Maize and Control of Weeds with Herbicides in the Irrigated Savanna

S. O. Ojeniyi, N. E. Egbe and T. I. Omotosho: Boron Nutrition of Amazon Cocoa (Cacao theobroma) in Nigeria I. Early Results of Fertilizer Trials

F. A. Gumbs and L. A. Simpson: Influence of Flooding and Soil Moisture Content on Elongation of Sugar Cane in Trinidad

T. A. T. Wahua, O. Babalola and M. E. Aken'ova: Intercropping Morphologically Different Types of Maize with Cowpeas: LER and Growth Attributes of Associated Cowpeas

F. F. Bebawi and A. F. Farah: Effects of Parasitic and Non-parasitic Weeds on Sorghum

F. F. Bebawi: Intraspecific Physiological Variants of Striga hermonthica

F. F. Bebawi and A. F. Farah: Effects of Nitrophoska and Atrazine on relations between Sorghum bicolor and Striga hermonthica

Book Reviews

Erratum

Index

C) Cambridge University Press $19^{81}$

Printed in Great Britain by Adlard \& Son Ltd.

Bartholomew Press, Dorking 